\title{
Study on the Influence Factors of Students Consumer Network Clothing Behavior
}

\author{
Yuemei Gao ${ }^{1, a}$
}

${ }^{1}$ Jiangxi Science \& Technology Normal University, Art College, Nanchang, Jiangxi, 330013

${ }^{a}$ email

Keywords: Student, Network Clothing Consumer Behavior, Influencing Factors

\begin{abstract}
With the rapid development of e-commerce industry in today's society, so that Internet consumption gradually become a modern shopping trends, and has become one of the schedules of people today an important part of life. Talented Students As the power of social development, because of its relation to other ideas in terms of population to be more avant-garde, therefore, naturally became a major force in online shopping. However, most college students have their own unique ideas for the network in terms of consumer behavior, it can be affected by many factors. In this paper, factors in-depth analysis of contemporary university network clothing consumer behavior, hoping to bring some help for the development of e-commerce and many network businesses.
\end{abstract}

\section{Introduction}

Students Internet clothing consumption behavior mainly refers to contemporary college students to make their own clothing needs are met, the use of virtual currency in cyberspace to exchange their own favorite clothing a behavioral activity. In-depth and rapid development of Internet commerce, to promote network consumption has gradually become one of the contemporary college students daily life as important components, especially college students own clothing consumption. However, Students' Network clothing consumer behavior is affected by many factors, into the Brand, commodity price and its factors are to some extent affected the network of college students clothing consumer behavior. Therefore, the relevant consumer e-commerce companies only factors of college students have to conduct a comprehensive analysis and control, and to take effective measures against these factors, which can make college students' spending power would be enhanced, so that self-interest is increased.

\section{Personal Factors Affecting College Students' Network Clothing Consumer Behavior}

According to the relevant economists found that dominate consumer buying behavior is a major factor in buyers own willingness to buy, and the willingness to buy and purchase directly linked to the attitude, the attitude of consumers to purchase by means of purchase intention to consumers the main factors affecting the buying behavior itself one of [1]. Consumer attitudes to computer applications, purchases experience and perception of product value and risk factors such as advance will severely affected by a series of studies have shown that consumers online consumer attitudes.

Students shopping experience is mainly reflected in the activity of shopping satisfaction, while shopping satisfaction depends Students of commodities gap purchase or service quality and expected beforehand between the determination to purchase the same goods or services and the quality of college students consumption expected or higher, for the satisfaction, the greater the gap between the higher satisfaction. Conversely Students expected consumption than the former, was not satisfied, the greater the gap, the less satisfaction. According to relevant survey, the network overall consumer satisfaction with online consumers spending decisions has a very important influence [2]. In addition, college students consumer decisions to its own consumption experience has a direct correlation in the past, the purchase process, e-business attitude, quality of products and services like many other aspects of satisfaction, willingness to spend will be on College Students' Network Consumption great impact. 
One of the main factors in college students buy online clothing products are emotions and feelings also affect students' network consumer behavior. Students as well as emotional emotional experience for many consumers, allowing college students to carry out consumption activities in some way. According to relevant survey research shows that college students during network engineering clothing consumption, which itself can cause great emotional impact on the students' consumption decisions. Thus, form and distributed manner by means of the network information can shadow effect on consumer sentiment about the consumer to determine search elements and consumption decisions of information, so that consumers Students clothing consumer behavior suffer a certain degree of influence.

The so-called consumer motivations mainly refers to the clothing or consumer services purchased intrinsic motivation. Students felt only when they buy from the network can make their own clothing and dress clothing requirements to meet the needs of a certain degree, so that students can make the purchase and consumption behavior [3]. Therefore, the students of consumer motivation is one of the main factors on consumer behavior about progress.

Students' perception of the value of the network clothing, mainly by means of trade-offs and contrast need to buy clothes to pay the costs of the goods and clothing can bring value, so that the garment be integrated evaluation. According to relevant survey, the goods or services and other perceived value and perceived costs, benefits, and risk factors have a strong relationship. Consumer value perception is one of the main factors that affect students' network consumer behavior.

\section{External Factors Affect Students' Network Clothing Consumer Behavior}

Commodity price is one of the main external factors that affect students' network clothing consumer behavior. Because college students shopping group has a certain degree of particularity, they lack stable income and financial resources, resulting in a very direct impact on the price of apparel products will students' network of consumer behavior [4]. According to relevant survey, the price advantage of the presence of apparel products to be more competitive with network marketing. From the survey data show that China's Internet Development Center, the main factors driving the development of China's consumer network include the ability to save time, the price is cheaper, more convenient to purchase and so on, we can see, the price factor for college students online clothing consumer behavior plays a key leading effect.

One consumer guide consumers in most major brand impact factor, which is not only reflected in the life of the display, the network consumption is significant. The main reason for this phenomenon is because most online shopping there is great uncertainty, when consumers buy goods take great risk, therefore, allow the brand to protect consumer behavior brings a to insurance. In addition, it is possible to allow consumers to choose the brand of the time and costs associated with product information searches have been reduced to some extent.

The so-called business website primarily for consumers and businesses to conduct marketing commodity trading network platform, we can see the network in the process of consumption, commerce site has a very important role. The more commerce site on track, with a larger scale, its own search function will be more simple and powerful, so that it can contribute to consumer goods to buy, so that time and costs can be reduced [5]. According to relevant survey, consumer spending during the course of the network, the influence of the main reasons commerce site in store traffic and sales amount in the cost of a search for information.

Mainly refers to the so-called trust on the basis of certain conditions, the level of trust on the other party. This network has a very important influence consumer behavior, network consumption is mainly implemented by means of the Internet consumer activity, which prompted many uncertainties exist between consumers and businesses, the degree of trust between the two sides will have a serious impact. Thus, if the lack of network marketers can allow consumers to trust can be trusted, can also cause some impact on the students' network clothing consumer behavior.

The so-called word of mouth mainly refers to people through word of mouth, to evaluate the satisfaction and the exchange of goods or services. The IWOM mainly refers to information on their evaluation of the project, the evaluation of the accumulation and dissemination of the network. 
Network quality of goods, by means of a good reputation will be even more persuasive, able to convince consumers to consume a certain extent, [6]. For now, the current business website, word of mouth method is mainly divided into two types, one is to show by means of a score, the other is telling the aid of instruments or Photo Gallery to reflect.

\section{Conclusion}

In summary, with the current e-commerce and Internet technology development and innovation, online shopping has become a modern people's daily life integral to the structure. As the main force of network consumption in contemporary college students, is largely bound to affect the development of network consumption. Therefore, only the main factors for students' network to do to fully understand consumer behavior and analysis in order to promote the development of e-business marketing strategy of promoting rapid business development and progress.

\section{Acknowledgements}

Dr. Scientific Research Fund Project of Jiangxi Science \& Technology Normal University: Film Industry in China since the Reform and Opening and Countermeasures.

\section{References}

[1] He Jianhua. Factors Affecting Buying Behavior - college students as research objects [J]. Jilin Institute of Business Technology, 2014, 02: 48-50 + 58.

[2] Wang Zhongjiang. Empirical Study of Factors Affecting College Students Spending Intentions clothing industry as an example [J]. Shenyang Institute of Engineering (Social Science Edition), 2014, 02: 172-175.

[3] Zhou Changchun, Zhong Shu. Clothing Consumption Behavior of College Students and Affecting Factors - Based on a survey of college students in Yunnan [J]. Jiangsu Buyer theory, 2012,11: 29-31.

[4] Factors Affecting College Students' Internet Li Wen, Wu Mengyun Yangtze River Delta region of green consumer behavior research [J]. Chinese management information, 2015, 01: 188-191.

[5] Zuo Zhenpeng, Zhao Taiyang, Jin Jia. college students online shopping online shopping consumer preferences and behavior factors - Take Jilin University 1877 samples Example [J]. Radio and TV University, 2016,01: 117-118. 